\title{
Üniversite Öğrencilerinin Yabancı Dil Öğrenme Zorluklarını Yaşama Düzeyleri $^{1}$
}

\author{
Murat BAYIR ${ }^{2}$ ve Rüștü YEŞIL ${ }^{3}$
}

$\ddot{O} z$

$\mathrm{Bu}$ araştırmanın amacı, üniversite dil hazırlık sınıfında yabancı dil öğrenen öğrencilerin yaşamış oldukları öğrenim zorluklarını belirlemektedir. Araștırma, tarama modelinde yürütülen betimsel ve nicel bir çalıșma özelliği tașımaktadır. Kırgız-Türk Manas Üniversitesi yabancı dil hazırlık sınıflarında dil eğitimi alan 495 öğrenci araşıırmanın çalışma grubunu oluşturmuştur. Araştırmanın verileri, "Kişisel Bilgi Formu" ve "Yabancı Dil Öğrenme Zorlukları Ölçeği (YDÖZÖ)" ile toplanmıştır. YDÖZÖ, 5 faktör altında toplanmış 29 maddelik beşli likert tipi bir ölçektir. Ölçeğin KMO değeri 0,937; Bartlett Testi değerlerinin $\times 2=5707,914$; $s d=406$; $p<0,001$; Cronbach alpha güvenirlik katsayıs1 ise 0,923 'tür. Veriler üzerinde aritmetik ortalama, standart sapma, t testi, Anova, Tukey ve korelasyon testi analizleri yapılmıştır. Fark ve ilişki testlerinin yorumlanmasında $\mathrm{p}<, 05$ düzeyi anlamlılık için yeterli kabul edilmiştir. Araştırma sonunda öğrencilerin en fazla farklılıklara uyum sağlama faktöründeki zorlukları yașadıkları; cinsiyet, ana dil, bilinen dil sayısı, ülkelerinde konuşulan dil sayısı, ailenin Kırgızistan'da yaşıyor olma durumu ve öğrenim görülecek bölümün niteliği değişkenlerine göre bazı faktörlerdeki zorlukların yaşanma düzeylerinin anlamlı düzeyde farklılaştı̆̆ı belirlenmiştir.

Anahtar Kelimeler: Yabancı dil öğrenme, Öğrenme zorlukları, Üniversite öğrencisi

\section{The Levels of Difficulties University Students Experience in Learning Foreign Languages}

\begin{abstract}
The aim of this study is to determine the difficulties in learning foreign languages that students at preparatory course have experienced. The research contents a descriptive and quantitative work carried out in the screening model. The study group of the research consisted of 495 students who got language education in foreign language preparatory classes of Kyrgyz-Turkish Manas University. The data of the study was collected by "Personal Information Form" and "Foreign Language Learning Scale of Difficulties (FLLSD)".FLLSD is a five-point Likert-type scale consisting of 29 items assembled under 5 factors. KMO value of the scale was 0.937 ; The Bartlett Test values for $\mathrm{x} 2=5707$, 914; $\mathrm{SD}=406 ; \mathrm{p}<0.001$; The Cronbach alpha reliability co-efficient is 0.923 . Arithmetic mean, standard deviation, $\mathrm{t}$ test, Anova, Tukey and correlation test analyzes were carried out with the data. In the interpretation of difference and relationship tests, $\mathrm{p}<0.05$ level was considered to be enough for significance. At the end of the research, according to the students' different factors such as experiencing difficulties in supplying, gender, mother tongue, number of known languages, number of languages spoken in their countries, a status of the family living in the Kyrgyzstan and differences in the nature of the department to be studied it was determined that the level of facing difficulties in some factors differed considerably.
\end{abstract}

Key Words: Foreign language learning, Learning difficulties, University student

\section{Atıf İçin / Please Cite As:}

Bayır, M. ve Yeşil, R. (2020). Üniversite öğrencilerinin yabancı dil öğrenme zorluklarını yaşama düzeyleri. Manas Sosyal Arasstrmalar Dergisi, 9(3), 1479-1493.

Geliş Tarihi / Received Date: 23.07.2019

Kabul Tarihi / Accepted Date: 05.05.2020

\footnotetext{
${ }^{1}$ Bu çalışma, KTMÜ Sosyal Bilimler Enstitüsü Eğitim Bilimleri Anabilim Dalında hazırlanan “Öğrencilerin Yabancı Dil Hazırlık Eğitiminde Karşılaştıkları Öğrenim Zorlukları Ve Çözüm Önerileri” adlı yüksek lisans tezinden üretilmiştir.

2 Kırgiz-Türk Manas Üniversitesi Yabancı Diller Yüksekokulu, mrdbyr@gmail.com - ORCID: 0000-0003-4887-7138

3 Prof. Dr. Kırgizistan-Türkiye Manas Üniversitesi Edebiyat Fakültesi/Ahi Evran Üniversitesi Eğitim Fakültesi, ryesil40@gmail.com - ORCID: 0000-0002-8839-0431
} 


\section{Giriş}

İletişim ve ulaşım teknolojilerinde yaşanan gelişmelerle birlikte dünya bir köy haline gelmiş; insanlar ve kültürler arasındaki etkileşim açısından coğrafi uzaklıklar sorun olmaktan önemli ölçüde çıkmıştır. Bununla birlikte bireylerin bu teknolojiden yararlanabilecek kadar dil yeterliklerine sahip olmalarının iletişim ve etkileşimin niteliği üzerinde önemli etkisinin olduğu belirtilmelidir (Altın ve Saracaloğlu, 2018, s. 138; Soyupek, 2007, s. 1571). Bununla birlikte bireylerdeki dil yeterliklerinin iyileştirilmesi konusunda alınan mesafenin, teknolojik altyapıdaki iyileşmelere oranla daha yetersiz kaldığı söylenebilir.

İnsanların özellikle farklı dilleri bilme ve kullanabilme konusundaki yetersizlikleri, iletişim ve etkileşime uygun bu ortamsal şartlardan yeterince yararlanabilmesini güçleştiren en önemli etkenlerden biri olarak nitelenebilir (Erişti, Polat ve Erdem, 2018, s. 356; Arslan, 2009, s. 309-310; Gömleksiz ve Özkaya, 2012, s. 496; Haznedar, 2010, 747). Bu gerçeği fark eden birey ve toplumların, farklı dilleri öğrenme yönünde büyük çaba gösterdikleri; bu çerçevede önemli yatırımlarda bulundukları dikkat çekmektedir (Arslan, 2009, s. 309; Yolcu, 2002, s. 21; Gömleksiz ve Özkaya, 2012, s. 497). Ülke çapında yabancı dille eğitim veren okulların açılması; her yaş düzeyine dönük yabancı dil kurslarının düzenlenmesi, okul öncesi eğitim programlarına kadar yabancı dil derslerinin yerleştirilmiş olması, yabancı dil öğretimi ile ilgili birçok bilimsel ve sosyal içerikli faaliyetlerin düzenlenmesi ve bireylerin farklı dilleri öğrenmeye teşvik edilmesi bu çabaların yalnızca bir kısmını oluşturmaktadır (Haznedar, 2010, s. 748-749; Altın ve Saracaloğlu, 2018, s. 137; Yaman, 2018, s. 162-163).

Yabancı/farklı dilleri bilme ve kullanabilme yeterlikleri, özellikle 21. Yüzyılın arzulanan/hedeflenen insan/vatandaş tipinin temel özelliklerinden biri olarak kabul edilmektedir (Arslan, 2009, s. 310; Haznedar, 2010, s. 747; Altın ve Saracaloğlu, 2018, s. 137). Soyupek'e (2007, s. 1571) göre yabanc1 dil bilmenin insanlara bireysel, sosyal ve mesleki sağlayacağı faydalar dikkate alındığında bu özelliğin yetişmiş insanın temel vasfi sayılması gerektiği savunulmaktadır. Başka bir ifade ile olabildiğince farklı dilleri bilip kullanabilmenin günümüzde, modern toplumlarda etkin bir birey olabilmenin temel gereklerinden biri olarak algilandığı söylenebilir.

Her şeyden önce birey ve toplumlardaki yabancı dil öğrenmeye ilişkin bu farkındalık durumunun, ülke ve toplumların geleceği açısından önemli ve memnuniyet verici olduğu belirtilmelidir. Bununla birlikte aynı memnuniyet verici durumun, yabanc1 dil öğrenme ya da öğretmede tesis edilemediği de belirtilmelidir (Haznedar, 2010, s. 753; Altın ve Saracaloğlu, 2018, s. 137; Erişti, Polat ve Erdem, 2018, s. 356; Soyupek, 2007, s. 1572). Türkiye'de yabanc1 dil öğrenme-öğretme problemine ilişkin çalışmaları derledikleri araştırmalarında Suna ve Durmuşçelebi (2013, s. 20) "bu çalışmalar Türkiye'de yabancı dil öğrenmeöğretme probleminin var olduğuna işaret etmektedir; ancak araştırma ve çalışma konularının çeşitliliği bu problemin tek bir nedeninin olmadığını göstermektedir" demektedirler.

Alanyazın incelendiğinde yabancı dil öğretimi ya da öğrenimi ile ilgili çok sayıda bilimsel çalışma yapıldığı; buna karşıllı bu çalışmaların önemli bir kısmında bilim insanı, yazar ve düşünürlerin yabancı dil öğretiminde önemli sorunlar ve zorluklar yaşandığını sıklıkla vurguladıkları dikkati çekmektedir (Soyupek, 2007, s. 1572; Yolcu, 2002, s. 24; Gömleksiz ve Özkaya, 2012, s. 497; Altın ve Saracaloğlu, 2018, s. 137; Yaman, 2018, s. 161). Suna ve Durmuşçelebi (2013, s. 20) politika yanlışlıklarını, dilbilgisi ağıllıklı yöntemlerin kullanılmasının, ders saati yetersizliği ve öğrencilerin yeterince zaman ayıramamalarının, kalabalık sınıfların, yanlış ölçme ve değerlendirme uygulamalarının, hizmet içi ve hizmet öncesi eğitim çalısmalarının niteliksizliğinin farklı araştırmalarda öne çıkan sorunlar olduğunu belirtmektedirler. Haznedar (2010, s. 753) ise öğretmenlerin yabancı dil eğitiminde yaşadıkları sorunlar incelendiğinde ilk sıralarda öğrencilerin bireysel farklılıklarının, motivasyon eksiklerinin, dil öğrenme için ayrılan zaman azlı̆̆1 ve kalabalık sınıflarda eğitim yapılıyor olmasının geldiğini; bunların yanı sıra, öğretim malzemesi yetersizlikleri, öğretmenlerin modern dil öğretim yöntemi konusundaki yetersizlikleri gibi etkenlerin de önemli sorun ve zorluklara yol açtı̆̆ını ifade etmektedir. Benzer tespitler farklı bilim insanları tarafindan da yapılmışır.

Yukarıda örneklenen araştırmalarda ortaya konulan yabancı dil öğretiminde karşılaşlan sorun ve zorlukların bir kısmının fiziksel altyapı yetersizlikleri, politika yanlışlıkları ve kültürel ortamla (Haznedar, 2010, s. 753; Erişti, Polat ve Erdem, 2018, s. 356; Yaman, 2018, s. 161); buna karşllı daha önemli kısmının ise uygulanan eğitim programları, öğretmen ve öğrenci yeterlikleri, öğrencilerin öğrenme alışkanlıkları ve sorumluluk alma düzeyleri ile eğitimin sosyokültürel ortamı ile ilişkilendirildiği dikkati çekmektedir (Carnell, 2005; Gömleksiz ve Özkaya, 2012, s. 499-500; ; Hughes, 2001; Tatlı ve Aksoy, 2017, s. 137; 
Sierra, 2009; Soyupek, 2007, s. 1572). Arslan (2009, s. 309-311) yabanc1 dil öğretimi ile ilgili olarak yaşanan sorunlar arasında teknolojik araçlardan etkin yararlanamama, motivasyon eksikleri, öğretmenlerin yöntem yanlışları, konuşulan dilden ziyade gramer odaklı dil eğitimi uygulamalarına öncelik verilmesi ve öğretmen yetersizlikleri sorunlarını saymaktadır. Haznedar (2010, s. 753) ise yabancı dil öğretiminde özellikle öğretmenlerin sözel iletişime dayalı yöntemleri kısmen de olsa kullanabilirlerken uygulamalı öğretim yöntem ve tekniklerinden yararlanma konusunda önemli yetersizlikler içerisinde oldukları, ölçme ve değerlendirme uygulamalarının nitelik sorunlarının bulunduğunu; yapılan hizmet içi eğitim çalışmalarının da bu yönde bir katma değer oluşturamadığını, özellikle yabanc1 dil öğretimi açısından bir standart oluşumunun da tesis edilemediğini belirtmektedir. Ona göre özellikle öğretmen yetiştirme süreçlerinde adaylara öğretim yeterliklerinin kazandırılması ve bir standart oluşturabilme önemli bir gereklilik olarak ortaya çıkmaktadır. Altın ve Saracaloğlu (2018, s. 155-158), 1996-2016 yılları arasında Türkiye'de yapılmış 117 tez çalş̧masının incelenmesi ve öğretmenlerle yapılan görüşmeler sonunda öğrencilerin temel dil becerilerinin öğretiminde uygulanan yöntemlerin öğrencilerin ilgilerini çekmediğini; bazı kelime türleri ve dilbilgisi yapılarının öğrenilmesinde/öğretilmesinde zorluklar yaşandığını, İngilizce öğrenmenin okul başarısı ve girilecekteki sınav başarısı üzerinde etkili olmaması nedeniyle yeterince önemsenmediğini belirlemişlerdir.

Hiç şüphesiz bu sorun kaynaklarının her biri, yabancı dil öğretiminin başarıya ulaşmasını olumsuz yönde etkilemektedir. Bunları her birinin ayrıntılı olarak araştırılması ve mücadele edilmesi önemlidir. Nitekim Altun ve Saracaloğlu (2018, s. 138) çalışmalarında Türkiye'de İngilizce öğretimi alanında yapılan tezleri incelemişler ve doktora düzeyinde ve deneysel desene dayalı tez çalışmalarının az olduğunu belirlemişlerdir. Bununla birlikte daha büyük enerji ve imkanların, öğretmen yeterlikleri, öğrenci tutum ve davranışları ile eğitim programları ile ilgili sorunların aşılması yönünde sarf edilmesi gerektiği söylenebilir. Özellikle eğitim bilimci ve öğretmenlerin enerji ve imkânlarını daha çok yabancı dil öğretimi süreçlerine odaklamalarının yararlı olacağı belirtilmelidir (Yalçın, 2013; Tatlı ve Aksoy, 2017; Yaman, 2018; Soyupek, 2007). Bu nedenle yabancı dil öğrenme ve öğretme süreçlerinde uygulanan programları, bu süreçte eğitimci olarak rol alan öğretmenlerin öğretim yeterlikleri ile öğrencilerin yabanc1 dil öğrenme konusundaki alışkanlık, tutum ve davranışlarının farklı yönlerden araştırmalara konu edilmesi önem arz etmektedir.

Modern eğitim kuramlarının sıklıkla vurguladığı üzere bu problemlere daha öğrenci merkezli bakabilmenin yararlı olacağı söylenebilir. Başka bir ifade ile yaşanan yabancı dil öğretimi sorunlarına kaynaklık eden durumların, onları bizzat yaşayan ve çok yönlü olarak olumsuz etkilenen öğrenci gözüyle değerlendirilmesi doğru bir tutum olarak değerlendirilebilir. Özellikle de yaşanan sorunların somut göstergeleri olan zorlukları tecrübe etmiş ve çıkış yolu aramış öğrenciler tarafindan hissedilen ve gözlenen boyutlarının belirlenmeye çalışılması, alınabilecek tedbirler ya da atılacak adımların tayin edilmesinde daha somut yol göstericiler olabilirler. Bu araştırma, temel olarak böyle bir bakış açısından hareket ederek tasarlanmıştır. Öğrencilerin yabancı dil öğrenme süreçlerinde yaşadıkları öğrenim zorlukları ve yaşama düzeylerini belirlemek, araştırmanın temel problemini oluşturmaktadır.

\section{Araştırmanın Amacı}

$\mathrm{Bu}$ araştırmanın temel amacı; üniversite yabancı dil hazırlık sınıflarında eğitim gören öğrencilerin yabanc1 dil öğrenirken yaşadıkları zorlukları ve yaşama düzeylerini farklı değişkenler açısından belirlemektir. Böylelikle, öğrenci ve öğretim elemanları açısından yabancı dil öğrenme ve öğretmenin kolaylaştırılması ve yabancı dil eğitim programlarının tasarlanması çerçevesinde kullanılabilecek verilerin temin edilmesi amaçlanmıştır. Bu zorlukları bizzat yaşayan öğrencilerin öğrenme tecrübelerine dayanarak tespit edilmeye çalışlan zorlukları konu edinmesi, sonuçlarının da uygulanabilirliği ve gerçekçiliği açısından araşıtırmaya ayrı bir değer kattığı düşünülmektedir. Bu genel amaç ve önem çerçevesinde araştırmada başlica şu sorulara cevap aranmiştır:

1. Yabanc1 dil öğrenme süreçlerindeki üniversite öğrencileri hangi zorlukları ne düzeyde yaşamaktadırlar?

2. Öğrencilerin yabancı dil öğrenirken yaşadıkları zorlukların demografik etkenlere (cinsiyet, öğrenim görülecek bölüm, ana dil, yaşadıkları ülkede yoğun olarak kullanılan dil sayısı, öğrenmeye çalıştıkları yabancı dil, ailelerinin Kırgızistan'da yaşıyor olma durumları) göre farklılaşmakta mıdır?

3. Zorlukların yaşanma düzeyi ile dil becerisi akademik başarı puanları arasında bir ilişki bulunmakta midir? 


\section{Yöntem}

\section{Araştırma Modeli}

Araştırmada, üniversite yabancı dil hazırlık sınıflarında eğitim alan öğrencilerin, yabancı dil öğrenirken yaşadıkları zorluklar ve yaşanma düzeyleri farklı değişkenler açısından nicel ölçme araçları ile betimlenmeye çalışılmıştır. Bu nedenle araştırma; tarama modelinde yürütülen, betimsel ve nicel bir çalışma özellik taşımaktadır (Balc1, 2015, s. 15; Karasar, 2012, s. 76-79).

\section{Çalışma Evreni - Örneklem}

Araştırmanın çalısma evrenini Kırgızistan-Türkiye Manas Üniversitesi (KTMÜ) Yabancı Diller Yüksekokulu Hazırlık Sınıfinda yabancı dil eğitimi alan toplam 1272 öğrenci oluşturmaktadır (http://oidb.manas.edu.kg/ss.php [Erişim: 16.06.2018]).

Araştırmanın örneklemi tesadüfi örnekleme tekniği ile belirlenmiştir. Veri toplandığı gün öğle öncesi kurslarda eğitim alan ve ankete gönüllü kattlım sağlamak isteyen 495 öğrenci, araştırmanın örneklem grubunu oluşturmuştur. Öğrencilerin araştırmaya konu edilen demografik değişkenlere göre dağıllımı Tablo 1'de sunulmuştur:

Tablo 1. Calıs̆ma Grubunun Demografik Özelliklerine Göre Dağgllmlarn (n=495)

\begin{tabular}{|c|c|c|c|}
\hline Değişkenler & Alt gruplar & $\mathrm{f}$ & $\%$ \\
\hline \multirow{2}{*}{ Cinsiyet } & $\bar{K} 1 z$ & 350 & 70,7 \\
\hline & Erkek & 145 & 29,3 \\
\hline \multirow{5}{*}{ Barınilan Yer } & Öğrenci Yurdu & 204 & 41,2 \\
\hline & Ailesi ile birlikte & 127 & 25,7 \\
\hline & Öğrenci evi & 35 & 7,1 \\
\hline & Diğer (akraba yanı, otel vb.) & 122 & 24,6 \\
\hline & Boş & 7 & 1,4 \\
\hline \multirow{5}{*}{$\begin{array}{l}\text { Üniversite Eğitimi Görecekleri Bölümlerin } \\
\text { Türü }\end{array}$} & Sözel & 75 & 15,2 \\
\hline & Sayısal & 227 & 45,9 \\
\hline & Eşit ağırlık & 108 & 21,8 \\
\hline & Genel yetenek & 34 & 6,9 \\
\hline & Boş & 51 & 10,3 \\
\hline \multirow{4}{*}{$\begin{array}{l}\text { Yaşanılan ülkede yoğun olarak konuşulan dil } \\
\text { sayısı }\end{array}$} & Bir dil & 63 & 12,7 \\
\hline & İki dil & 336 & 67,9 \\
\hline & Üç dil ve fazla & 92 & 18,6 \\
\hline & Boş & 4 & 0,8 \\
\hline \multirow{4}{*}{ Ana dilleri } & Kırg1z Türkçesi & 425 & 85,9 \\
\hline & Türkiye Türkçesi & 39 & 7,9 \\
\hline & Diğer Diller & 29 & 5,8 \\
\hline & Boş & 2 & 0,8 \\
\hline
\end{tabular}

\section{Verilerin Toplanması ve Veri Toplama Araçları}

Araştırmanın verileri, "Kişisel Bilgi Formu" ile araştırmacılar tarafından geliştirilen "Yabancı Dil Öğrenme Zorlukları Ölçeği” ile toplanmıştır. Okul yönetiminden izin alındıktan sonra araştırmacılar sınıfları gezerek gerekli açıklamalarda bulunmuş; formlar gönüllü öğrencilere dağıtılıp ders sonunda öğretmenlere teslim etmeleri istenmiştir. Öğretmenlerde toplanan formlar bir gün sonra araştırmacılar tarafindan teslim alınmıştır.

Kişisel Bilgi Formu: Araştırmanın bağımsız değişkenlerine ilişkin verileri toplamak üzere kullanılan ve 7 maddeden oluşan bir veri toplama aracıdır.

Yabancı Dil Öğrenme Zorluklar Ölçĕğ (YDÖZÖ): Öğrencilerin yabanc1 dil öğrenme süreçlerinde yaşadıkları öğrenim zorluklarını ve yaşanma düzeylerini belirlemek amacıyla kullanılan geçerli ve güvenirlik özellikleri test edilmiş bir ölçektir (Büyüköztürk, 2012; Eroğlu, 2008; Balc1, 2015). Ölçek 5 faktör altında toplanmış 29 maddeyi içeren beşli likert tipi bir veri toplama aracıdır. Ölçeğin faktörleri; "Öğretmen Kaynaklı Zorluklar (ÖKZ)", "Materyal / Ölçme Değerlendirme Kaynaklı Zorluklar (MÖKZ)", "Öğrenme Alışkanlığı Kaynaklı Zorluklar (ÖAKZ)", "Farklılıklara Uyum Sağlama Kaynaklı Zorluklar (FUKZ)" ve "Psikososyal Ortam Kaynaklı Zorluklar (POKZ)" adlarını taşımaktadır. Dereceleme seçenekleri ise (0) Hiç/Çok az”, “(1) Az”, “(2) Biraz/Kısmen”, “(3) Fazla” ve “(4) Çok fazla” ifadelerini içermektedir. Araştırmacılar tarafindan yapılan geçerlik analizleri sonucunda ölçeğin KMO değeri 0,937; Bartlett Testi 
değerlerinin $\mathrm{x} 2=5707,914 ; \mathrm{sd}=406 ; \mathrm{p}<0,001$ olarak belirlenmiştir. Ölçeğin geçerlik ve güvenirlik özelliklerini yansıtan değerler Tablo 2'de özetlenmiştir:

Tablo 2. Yabanc Dil Öğrenme Zorluklar Ölçeğinin geçerlike ve Güvenirlik Değerleri

\begin{tabular}{llcccc}
\hline \multirow{2}{*}{ Faktör Adı } & $\begin{array}{c}\text { Madde } \\
\text { Sayısı }\end{array}$ & $\begin{array}{c}\text { Faktör Yükü } \\
\text { Aralıkları }\end{array}$ & Özdeğer & $\begin{array}{c}\text { Açıklanan Varyans } \\
\text { Miktari (\%) }\end{array}$ & $\begin{array}{c}\text { Cronbach } \\
\text { Alpha }\end{array}$ \\
\hline ÖKZ & 8 madde &, $560-, 725$ & 9,512 & 32,800 & 0,893 \\
MÖKZ & 6 madde &, $568-, 674$ & 2,271 & 7,830 & 0,814 \\
ÖAKZ & 6 madde &, $548-, 672$ & 1,640 & 5,656 & 0,812 \\
FUKZ & 5 madde &, $601-, 751$ & 1,297 & 4,473 & 0,741 \\
POKZ & 4 madde &, $449-, 782$ & 1,178 & 4,062 & 0,695 \\
\hline YDÖZÖ & 29 madde &, $450-, 775$ & --- & 54,821 & 0,923 \\
\hline
\end{tabular}

\section{Verilerin Analizi}

Verileri üzerinde, araştırmanın amaçları doğrultusunda aritmetik ortalama, standart sapma, ilişkisiz örneklem t testi, Anova testi, Tukey testi ve Pearsns' $r$ testi analizleri yapılmıştır. Fark ve ilişki testlerinde $\mathrm{p}<, 05$ düzeyi anlamllık için yeterli kabul edilmiştir. Diğer taraftan aritmetik ortalama değerleri için " 0,00 0,80 arası hiç/çok az", " 0,81 - 1,60 arası az", "1,61 - 2,40 arası biraz", "2,41 - 3,20 arası fazla" ve "3,21 4,00 arası çok fazla" olarak tanımlanmış ve yorumlanmıştır.

\section{Bulgular}

Veriler üzerinde yapılan analizler sonunda dil hazırlık sınıfinda yabancı dil eğitimi alan üniversite öğrencilerinin yaşadıkları öğrenim zorluklarına ve bazı değişkenlere göre bu zorlukların yaşanma düzeylerine ilişkin bulgular aşağıda sunulmuştur.

Yabancı Dil Eğitimi Süreçlerinde Öğrencilerin Yaşadıkları Öğrenim Zorluklarına İlişkin Bulgular

Tablo 3. Ögrencilerin Yabancı Dil Ögrenirken Yaşadıkları Zorluklarn Faktörlere Göre Dağılımı

\begin{tabular}{|c|c|c|c|c|}
\hline Faktörler & $N$ & $\overline{\mathbf{x}}$ & Ss & Düzey \\
\hline Öğretmen Kaynaklı Zorluklar (ÖKZ) & 495 & 2,13 & 86 & Biraz \\
\hline Materyal / Ölçme Değerlendirme Kaynaklı Zorluklar (MÖKZ) & 495 & 2,41 & ,83 & Fazla \\
\hline Öğrenme Alışkanlığı Kaynaklı Zorluklar (ÖAKZ) & 495 & 2,49 & ,81 & Fazla \\
\hline Farklılıklara Uyum Sağlama Kaynaklı Zorluklar (FUKZ) & 495 & 2,73 & ,69 & Fazla \\
\hline Psikososyal Ortam Kaynaklı Zorluklar (POKZ) & 495 & 2,67 & ,88 & Fazla \\
\hline
\end{tabular}

Tablo 3'te üniversite öğrencilerinin yabancı dil öğrenirken yaşadıkları zorlukları yaşama düzeylerine ilişskin değerlerin faktörlere göre $X^{-}=2,13$ ile 2,73 arasında değerler aldığı görülmektedir. Öğrenciler FUKZ faktöründeki zorlukları diğerlerine göre daha çok; ÖKZ faktöründeki zorlukları ise daha az yaşadıklarını belirtmişlerdir. Diğer taraftan yalnızca ÖKZ faktöründeki zorlukları biraz, diğerlerini ise fazlaca yaşadıklarını ifade etmişlerdir.

\section{Öğrencilerin Yabancı Dil Öğrenirken Yaşadıkları Zorlukların Demografik Etkenlere Göre Farklılaşma Durumlarına İlişkin Bulgular}

Öğrencilerin yabancı dil öğrenirken yaşadıkları zorlukların bazı değişkenlere göre farklılaşma durumuna ilişkin bulgular aşağıda sunuluştur. 
Öğrencilerin Yabancı Dili Öğrenirken Yaşadıkları Zorlukların Cinsiyetlerine Göre Farklılaşma Durumuna İlişkin Bulgular

Tablo 4. Yabanc Dil Öğrenmede Öğrencilerin Yaşadıklar Zorluklara İlişkin Dĕgerlendirmelerinin Cinsiyetlerine Göre Farkhlasma Durumu

\begin{tabular}{|c|c|c|c|c|c|c|c|c|}
\hline \multirow{2}{*}{ Faktörler } & \multirow{2}{*}{ Cinsiyet } & \multirow{2}{*}{$N$} & \multirow{2}{*}{$\bar{X}$} & \multirow{2}{*}{ Ss } & \multicolumn{2}{|c|}{ Levene Testi } & \multirow{2}{*}{$t$} & \multirow{2}{*}{$p$} \\
\hline & & & & & $F$ & $p$ & & \\
\hline \multirow{2}{*}{ ÖKZ } & $\mathrm{K}_{1 z}$ & 350 & 2,03 &, 82 & \multirow{2}{*}{2,849} & \multirow{2}{*}{,092 } & \multirow{2}{*}{4,307} & \multirow{2}{*}{,000 } \\
\hline & Erkek & 145 & 2,39 & ,91 & & & & \\
\hline \multirow{2}{*}{ M/ÖKZ } & $\mathrm{K}_{1 z}$ & 350 & 2,36 & 82 & \multirow{2}{*}{, 169 } & \multirow{2}{*}{ 681 } & \multirow{2}{*}{2,079} & \multirow{2}{*}{,038 } \\
\hline & Erkek & 145 & 2,53 &, 86 & & & & \\
\hline \multirow{2}{*}{ ÖAKZ } & $\mathrm{K}_{12}$ & 350 & 2,39 & ,79 & \multirow{2}{*}{,073 } & \multirow{2}{*}{, 787} & \multirow{2}{*}{4,451} & \multirow{2}{*}{,000 } \\
\hline & Erkek & 145 & 2,74 &, 79 & & & & \\
\hline \multirow{2}{*}{ FUKZ } & $K_{1 z}$ & 350 & 2,72 & ,69 & \multirow{2}{*}{,058 } & \multirow{2}{*}{,809 } & \multirow{2}{*}{,285 } & \multirow{2}{*}{,775 } \\
\hline & Erkek & 145 & 2,74 & ,68 & & & & \\
\hline \multirow{2}{*}{ POKZ } & $\mathrm{K}_{12}$ & 350 & 2,71 & ,88 & \multirow{2}{*}{,003 } & \multirow{2}{*}{,956 } & \multirow{2}{*}{1,376} & \multirow{2}{*}{,169 } \\
\hline & Erkek & 145 & 2,59 & ,90 & & & & \\
\hline
\end{tabular}

Tablo 4'te yabanc1 dil öğrenirken yaşadıkları zorlukları faktörlere göre kız öğrencilerin $X=2,03$ ile 2,72; erkek öğrencilerin ise $X=2,39$ ile 2,74 aralığında yaşadıklarını belirttikleri görülmektedir. Diğer taraftan ÖKZ, M/ÖKZ ve ÖAKZ faktörlerindeki zorlukları erkek öğrencilerin anlamlı düzeyde daha yoğun yaşadıkları; buna karşılık FUKZ ve POKZ faktörlerindeki zorlukları birbirlerine yakın yoğunlukta yaşadıkları belirlenmiştir. Diğer taraftan fark anlamlı olmamakla birlikte yalnızca POKZ faktöründeki zorlukların kız öğrenciler tarafından daha çok yaşandığı dikkati çekmektedir.

Öğrencilerin Yabancı Dili Öğrenirken Yaşadıkları Zorlukların Öğrenim Görmek İstedikleri Bölüm Gruplarına Göre Farklılaşma Durumuna İlişkin Bulgular

Tablo 5. Öğrencilerin Yabana Dili Öğrenirken Yaşadıklar Zorluklarn Öğrenim Görmek Istedikleri Bölüm Gruplarma Göre Farklilasma Durumuna İlişkin Bulgular

\begin{tabular}{|c|c|c|c|c|c|c|c|c|c|c|c|}
\hline Fak & Bölüm Grupları & $\mathbf{N}$ & $\bar{X}$ & $S s$ & & $K T$ & $s d$ & $K O$ & $F$ & $p$ & Tukey \\
\hline \multirow{4}{*}{ ON } & (1) Sözel & 75 & 1,81 & ,89 & & & & & & & $1-2$ \\
\hline & (2) Sayısal & 227 & 2,23 & ,84 & Gr. Aras 1 & 7,764 & 3 & 2,588 & 3,702 & ,012 & $1-4$ \\
\hline & (3) Eşit ağırlık & 108 & 1,96 &, 80 & Grup İçi & 307,645 & 440 & ,699 & & & \\
\hline & (4) Genel Yetenek & 34 & 2,34 &, 72 & Toplam & 315,410 & 443 & & & & \\
\hline \multirow{4}{*}{$\frac{N}{2}$} & (1) Sözel & 75 & 2,31 & 89 & & & & & & & -- \\
\hline & (2) Sayısal & 227 & 2,44 & ,83 & Gr. Aras1 & 1,808 & 3 & ,603 & ,871 & ,456 & \\
\hline & (3) Eşit ağırlık & 108 & 2,32 & ,82 & Grup İçi & 304,358 & 440 & ,692 & & & \\
\hline & (4) Genel Yetenek & 34 & 2,48 & ,66 & Toplam & 306,166 & 443 & & & & \\
\hline \multirow{4}{*}{$\frac{1}{0}$} & (1) Sözel & 75 & 2,30 & ,83 & & & & & & & $1-4$ \\
\hline & (2) Sayısal & 227 & 2,54 & ,80 & Gr. Aras1 & 5,731 & 3 & 1,910 & 3,145 & ,025 & $3-4$ \\
\hline & (3) Eşit ağırlık & 108 & 2,34 &, 71 & Grup İçi & 267,288 & 440 & 607 & & & \\
\hline & (4) Genel Yetenek & 34 & 2,80 & ,69 & Toplam & 273,019 & 443 & & & & \\
\hline \multirow{4}{*}{$\stackrel{N}{\stackrel{N}{p}}$} & (1) Sözel & 75 & 2,61 & ,72 & & & & & & & $\begin{array}{ll}-- \\
\end{array}$ \\
\hline & (2) Sayısal & 227 & 2,73 & ,68 & Gr. Aras1 & ,941 & 3 & ,314 & ,658 &, 578 & \\
\hline & (3) Eşit ağırlık & 108 & 2,69 & ,69 & Grup İçi & 209,566 & 440 & ,476 & & & \\
\hline & (4) Genel Yetenek & 34 & 2,80 & ,66 & Toplam & 210,507 & 443 & & & & \\
\hline \multirow{4}{*}{$\begin{array}{l}N \\
0 \\
0 \\
0\end{array}$} & (1) Sözel & 75 & 2,56 & ,81 & & & & & & & --- \\
\hline & (2) Sayısal & 227 & 2,65 & ,86 & Gr. Aras1 & 3,031 & 3 & 1,010 & 1,278 & ,281 & \\
\hline & (3) Eşit ağırlık & 108 & 2,79 & ,95 & Grup İçi & 347,758 & 440 & ,790 & & & \\
\hline & (4) Genel Yetenek & 34 & 2,74 & 94 & Toplam & 350,789 & 443 & & & & \\
\hline
\end{tabular}

Tablo 5'te üniversite öğrencilerinin yabancı dil öğrenirken yaşadıkları zorlukların öğrenim görecekleri bölümlerin niteliğine göre ÖKZ ve ÖAKZ faktörlerinde anlamlı düzeyde farklılaştığ1 ( $<<, 05)$; buna karşlık M/ÖKZ, FUKZ ve POKZ faktörlerinde böyle bir farklılaşmanın olmadığı görülmektedir ( $\mathrm{p}>, 05)$. $\mathrm{Bu}$ faktörlerdeki farklılaşmanın kaynağını belirlemek üzere veriler üzerinde TUKEY testi uygulanmıştır. ÖKZ faktöründeki zorlukları sayısal ve genel yetenek gerektiren bölümlerde öğrenim görecek öğrencilerin, sözel bölümlerde öğrenim görecek öğrencilere göre daha fazla yaşadıkları belirlenmiştir. Diğer taraftan 
ÖAKZ faktöründeki zorlukları ise genel yetenek bölümlerinde öğrenim görecek öğrencilerin sözel ve eşit ağılık bölümlerinde öğrenim göreceklere göre daha fazla yaşadıkları görülmüştür.

Öğrencilerin Yabancı Dili Öğrenirken Yaşadıkları Zorlukların Anadillerine Göre Farklılaşma Durumuna İlişkin Bulgular

Tablo 6. Yabanc Dil Öğrenmede Öğrencilerin Yaşadıklar Zorluklarn Anadillerine Göre Farkhlasma Durumu

\begin{tabular}{|c|c|c|c|c|c|c|c|c|c|c|c|}
\hline Fak. & Anadil & $N$ & $\bar{X}$ & Ss & & $K T$ & $s d$ & $K O$ & $F$ & $p$ & Tukey \\
\hline \multirow{3}{*}{ : } & (1) Türkiye Türkçesi & 39 & 2,48 & 97 & Gr. Aras1 & 12,638 & 2 & 6,319 & 8,726 &, 000 & $1-2$ \\
\hline & (2) Kırg1z Türkçesi & 425 & 2,07 & 83 & Grup İçi & 354,819 & 490 & ,724 & & & $3-2$ \\
\hline & (3) Diğer Diller & 29 & 2,59 & ,97 & Toplam & 367,456 & 492 & & & & \\
\hline \multirow{3}{*}{ 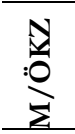 } & (1) Türkiye Türkçesi & 39 & 2,63 & 88 & Gr. Aras1 & 3,237 & 2 & 1,618 & 2,319 & ,099 & -- \\
\hline & (2) Kırg1z Türkçesi & 425 & 2,38 & ,82 & Grup İçi & 341,959 & 490 & 698 & & & \\
\hline & (3) Diğer Diller & 29 & 2,60 & ,94 & Toplam & 345,195 & 492 & & & & \\
\hline \multirow{3}{*}{ : } & (1) Türkiye Türkçesi & 39 & 2,76 & ,72 & Gr. Aras1 & 9,462 & 2 & 4,731 & 7,349 & ,001 & $1-2$ \\
\hline & (2) Kırgız Türkçesi & 425 & 2,44 & 80 & Grup İçi & 315,450 & 490 & 644 & & & $3-2$ \\
\hline & (3) Diğer Diller & 29 & 2,92 & ,90 & Toplam & 324,912 & 492 & & & & \\
\hline \multirow{3}{*}{ 党 } & (1) Türkiye Türkçesi & 39 & 2,83 & ,73 & Gr. Aras1 & ,527 & 2 & 263 & ,544 & ,581 & --- \\
\hline & (2) Kırg1z Türkçesi & 425 & 2,71 & ,69 & Grup İçi & 237,136 & 490 & ,484 & & & \\
\hline & (3) Diğer Diller & 29 & 2,77 & ,72 & Toplam & 237,663 & 492 & & & & \\
\hline \multirow{3}{*}{\begin{tabular}{l}
$N$ \\
\hdashline \\
\hdashline
\end{tabular}} & (1) Türkiye Türkçesi & 39 & 2,81 & 1,02 & Gr. Aras1 & 4,917 & 2 & 2,459 & 3,143 & ,044 & $2-3$ \\
\hline & (2) Kırgız Türkçesi & 425 & 2,70 & 86 & Grup İçi & 383,330 & 490 &, 782 & & & \\
\hline & (3) Diğer Diller & 29 & 2,98 & ,96 & Toplam & 388,248 & 492 & & & & \\
\hline
\end{tabular}

Tablo 6'da yabancı dil öğrenme sürecinde öğrencilerin öğrenim zorluklarını yaşama düzeylerinin ana dillerine göre ÖKZ, ÖAKZ ve POKZ faktörlerinde anlamlı düzeyde farklılaşırken (p<, 05) M/ÖKAZ ve FUKZ faktörlerinde farklılaşmadığı görülmektedir $(\mathrm{p}>, 05)$ görülmektedir. Bu faktörlerdeki farklılaşmanın kaynağını belirlemek üzere Tukey testi yapılmıştır. Tukey testi sonunda; ÖKZ ve ÖAKZ faktörlerindeki zorlukları, ana dili Türkiye Türkçesi ve diğer ana dillerdeki öğrencilerin ana dili Kırgız Türkçesi olan öğrencilere göre daha yoğun şekilde yaşadıkları; POKZ faktöründeki zorlukları ise diğer ana dillere sahip öğrencilerin Kırgız Türkçesi ana dilindeki öğrencilere göre anlamlı bir farkla daha yoğun yaşadıkları belirlenmiştir. Diğer taraftan faktörlerin her birinde Kırgız Türkçesi ana dilindeki öğrencilerin yabancı dil öğrenme süreçlerinde öğrenim zorluklarını daha az yaşadıkları dikkati çekmektedir.

Öğrencilerin Yabancı Dili Öğrenirken Yaşadıkları Zorlukların Yaşadıkları Ülkede Yoğun Olarak Konuşulan Dil Sayısına Göre Farklılaşma Durumuna İlişkin Bulgular

Tablo 7. Yabancı Dil Öğrenmede Öğrencilerin Yaşadıklarn Zorluklarn Yaşadıklar Ülkede Yoğun Olarak Konusulan Dil Sayısina Göre Farklilașma Durumu

\begin{tabular}{|c|c|c|c|c|c|c|c|c|c|c|c|}
\hline Fakt. & Dil Sayısı & $\mathbf{N}$ & $\bar{X}$ & Ss & & $K T$ & $s d$ & $K \boldsymbol{K}$ & $F$ & $p$ & Tuk. \\
\hline \multirow{3}{*}{$\frac{N}{0}$} & (1) Bir dil & 63 & 2,35 & 94 & Gr. Aras1 & 5,490 & 2 & 2,745 & 3,701 &, 025 & $1-2$ \\
\hline & (2) İki dil & 336 & 2,06 & ,83 & Grup İçi & 361,956 & 488 &, 742 & & & \\
\hline & (3) Üç ve fazla & 92 & 2,23 & 90 & Toplam & 367,446 & 490 & & & & \\
\hline \multirow{3}{*}{$\frac{N}{0}$} & (1) Bir dil & 63 & 2,52 & ,92 & Gr. Aras1 & 1,353 & 2 & ,676 & 960 & ,384 & --- \\
\hline & (2) İki dil & 336 & 2,38 & ,81 & Grup İçi & 343,878 & 488 &, 705 & & & \\
\hline & (3) Üç ve fazla & 92 & 2,46 & ,85 & Toplam & 345,231 & 490 & & & & \\
\hline \multirow{3}{*}{ O } & (1) Bir dil & 63 & 2,66 & ,80 & Gr. Aras1 & 4,277 & 2 & 2,138 & 3,261 & 039 & $1-2$ \\
\hline & (2) İki dil & 336 & 2,43 &, 78 & Grup İçi & 319,993 & 488 & ,656 & & & \\
\hline & (3) Üç ve fazla & 92 & 2,60 & 90 & Toplam & 324,270 & 490 & & & & \\
\hline \multirow{3}{*}{ 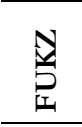 } & (1) Bir dil & 63 & 2,77 & ,72 & Gr. Aras1 & ,430 & 2 & 215 & ,445 & ,641 & --- \\
\hline & (2) İki dil & 336 & 2,71 &, 70 & Grup İçi & 236,002 & 488 & ,484 & & & \\
\hline & (3) Üç ve fazla & 92 & 2,77 & ,65 & Toplam & 236,432 & 490 & & & & \\
\hline \multirow{3}{*}{\begin{tabular}{l}
$N$ \\
\hdashline \\
\hdashline \\
\hdashline
\end{tabular}} & (1) Bir dil & 63 & 2,90 & ,95 & Gr. Aras1 & 4,083 & 2 & 2,042 & 2,598 & ,075 & --- \\
\hline & (2) İki dil & 336 & 2,63 &, 86 & Grup İçi & 383,504 & 488 & ,786 & & & \\
\hline & (3) Üç ve fazla & 92 & 2,69 & ,92 & Toplam & 387,587 & 490 & & & & \\
\hline
\end{tabular}


Tablo 7'de yabancı dil öğrenme sürecinde öğrencilerin yaşadıkları ülkede yoğun olarak konuşulan dil sayısına göre ÖKZ ve ÖAKZ faktörlerindeki öğrenim zorluklarını yaşama düzeylerinin anlamlı düzeyde farklılaştı̆̆1 $(\mathrm{p}<, 05)$; buna karşılık M/ÖKAZ, FUKZ ve POKZ faktörlerinde böyle bir farklılaşmanın olmadığ1 görülmektedir ( $\mathrm{p}>, 05)$. Farklılaşmanın kaynağını belirlemek üzere uygulanan Tukey testi sonunda; ÖKZ ve ÖAKZ faktörlerindeki zorlukları ülkesinde bir dil konuşulan öğrenciler tarafından anlamlı bir farkla daha çok yaşandığ belirlenmiştir. Diğer taraftan, 2 ile 3 ve daha fazla dilin konuşulduğu ülkelerden gelen öğrenciler arasında böyle bir farklılaşmanın olmadığı dikkat çekici olarak değerlendirilebilir.

\section{Öğrencilerin Yabancı Dili Öğrenirken Yaşadıkları Zorlukların Hazırlık Eğitimine Devam Ettikleri Dile Göre Farklılaşma Durumuna İlişkin Bulgular}

Tablo 8. Yabancı Dil Öğrenmede Öğrencilerin Yaşadıklar Zorluklarn Hą̧rlı Eğgitimine Devam Ettikleri Dile Göre Farkhlasma Durumu

\begin{tabular}{|c|c|c|c|c|c|c|c|c|c|c|c|}
\hline Fak. & Öğrenilen dil & $\mathbf{N}$ & $\bar{X}$ & Ss & & $K T$ & $s d$ & $K O$ & $F$ & $p$ & Tuk. \\
\hline \multirow{3}{*}{$\frac{N}{0}$} & (1) Türkiye Türkç. & 434 & 2,09 & 83 & Gr. Aras1 & 11,953 & 2 & 5,976 & 8,262 & 000 & $\overline{1-2}$ \\
\hline & (2) Kırg1z Türkç. & 30 & 2,74 & 1,01 & Grup İçi & 355,893 & 492 &, 723 & & & $3-2$ \\
\hline & (3) İng/Çince/Rusç & 31 & 2,07 & 91 & Toplam & 367,845 & 494 & & & & \\
\hline \multirow{3}{*}{ 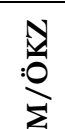 } & (1) Türkiye Türkç. & 434 & 2,39 & 81 & Gr. Aras1 & 2,688 & 2 & 1,344 & 1,921 & ,148 & $\begin{array}{ll}-- \\
\end{array}$ \\
\hline & (2) Kırg1z Türkç. & 30 & 2,69 & ,98 & Grup İçi & 344,226 & 492 &, 700 & & & \\
\hline & (3) İng/Çince/Rusç & 31 & 2,45 & 1,02 & Toplam & 346,914 & 494 & & & & \\
\hline \multirow{3}{*}{ Oي } & (1) Türkiye Türkç. & 434 & 2,44 & ,79 & Gr. Aras1 & 14,145 & 2 & 7,073 & 11,160 & ,000 & $1-2$ \\
\hline & (2) Kırg1z Türkç. & 30 & 3,12 & ,85 & Grup İçi & 311,807 & 492 & ,634 & & & $3-2$ \\
\hline & (3) İng/Çince/Rusç & 31 & 2,68 &, 74 & Toplam & 325,952 & 494 & & & & \\
\hline \multirow{3}{*}{$\stackrel{N}{P}$} & (1) Türkiye Türkç. & 434 & 2,70 & ,69 & Gr. Arası & 2,326 & 2 & 1,163 & 2,426 & ,089 & --- \\
\hline & (2) Kırg1z Türkç. & 30 & 2,96 &, 71 & Grup İçi & 235,866 & 492 & ,479 & & & \\
\hline & (3) İng/Çince/Rusç & 31 & 2,85 &, 70 & Toplam & 238,193 & 494 & & & & \\
\hline \multirow{3}{*}{ 点 } & (1) Türkiye Türkç. & 434 & 2,66 & ,88 & Gr. Aras1 & 2,753 & 2 & 1,376 & 1,749 & 175 & --- \\
\hline & (2) Kırg1z Türkç. & 30 & 2,97 & ,87 & Grup İçi & 387,205 & 492 & ,787 & & & \\
\hline & (3) İng/Çince/Rusç & 31 & 2,65 &, 87 & Toplam & 389,958 & 494 & & & & \\
\hline
\end{tabular}

Tablo 8'de yabancı dil öğrenme sürecinde öğrencilerin dil hazırlık eğitimi aldıkları dil türüne göre ÖKZ ve ÖAKZ faktörlerinde anlamlı düzeyde farklılaştı̆̆ı $(\mathrm{p}<, 05)$; buna karşılık M/ÖKZ, FUKZ ve POKZ faktörlerinde anlamlı düzeyde farklılaşmanın olmadığı ( $\mathrm{p}>$,05) görülmektedir. Farklılaşmanın kaynağını belirlemek üzere veriler üzerinde Tukey testi uygulanmıştır. ÖKZ ve ÖAKZ faktörlerindeki zorlukları Kırgız Türkçesi öğrenenlerin Türkiye Türkçesi ve diğer dilleri öğrenenlere göre anlamlı bir farkla daha yoğun yaşadıkları belirlenmiştir.

Öğrencilerin Yabancı Dili Öğrenirken Yaşadıkları Zorlukların Ailelerinin Yaşadıkları Ülkeye Göre Farklılaşma Durumuna İlişkin Bulgular

Tablo 9. Yabanc Dil Öğrenmede Öğrencilerin Yasadıklan Zorluklara İliskin Değerlendirmelerinin Ailelerinin Yasadıklar Ülkeye Göre Farkhlaşma Durumu

\begin{tabular}{|c|c|c|c|c|c|c|c|c|}
\hline \multirow{2}{*}{ Faktörler } & \multirow{2}{*}{ Cinsiyet } & \multirow{2}{*}{$\mathbf{N}$} & \multirow{2}{*}{$\bar{X}$} & \multirow{2}{*}{ Ss } & \multicolumn{2}{|c|}{ Levene Testi } & \multirow{2}{*}{$t$} & \multirow{2}{*}{$p$} \\
\hline & & & & & $F$ & $p$ & & \\
\hline \multirow{2}{*}{ ÖKZ } & Kirg1zistan & 441 & 2,09 &, 85 & ,109 &, 742 & 2,747 &, 006 \\
\hline & Diğer ülkeler & 51 & 2,44 & ,89 & & & & \\
\hline \multirow{2}{*}{ M/ÖKZ } & Kurg1zistan & 441 & 2,39 & 82 & 917 & ,339 & 1,174 & ,241 \\
\hline & Diğer ülkeler & 51 & 2,54 & ,92 & & & & \\
\hline \multirow{2}{*}{ ÖAKZ } & Kurg1zistan & 441 & 2,46 & ,80 & 1,884 & ,170 & 2,899 & ,004 \\
\hline & Diğer ülkeler & 51 & 2,80 &, 75 & & & & \\
\hline \multirow{2}{*}{ FUKZ } & Kırgizistan & 441 & 2,72 & ,69 & 1,043 & ,308 & 949 & ,343 \\
\hline & Diğer ülkeler & 51 & 2,82 & ,64 & & & & \\
\hline \multirow{2}{*}{ POKZ } & Kirg1zistan & 441 & 2,66 & ,88 & ,015 & ,902 & 1,316 & ,189 \\
\hline & Diğger ülkeler & 51 & 2,83 & ,89 & & & & \\
\hline
\end{tabular}

Sd: 490 
Tablo 9'da yabancı dil öğrenirken yaşadıkları zorlukları faktörlere göre ailesi Kırgızistan'da yaşayan öğrencilerin $X=2,09$ ile 2,72; diğer ülkelerde yaşayan öğrencilerin ise $X=2,44$ ile 2,83 aralı̆̆ında yaşadıklarını belirttikleri görülmektedir. Diğer taraftan ÖKZ ve ÖAKZ faktörlerindeki zorlukları ailesi diğer ülkelerde yaşayanların Kırgızistan'da yaşayanlara göre anlamlı düzeyde daha yoğun yaşadıkları $(\mathrm{p}<, 01)$; buna karşılık diğer faktörlerdeki zorlukların yaşanma düzeylerinde anlamlı bir farklılaşmanın olmadığ1 ( $\mathrm{p}>, 05)$ belirlenmiştir.

\section{Yaşanan Sorunların, Öğrencilerin Dil Başarı Puanları İle İlişki Durumuna Dair Bulgular}

Tablo 10. Yabanc Dil Öğrenmede Öğrencilerin Yasadıklar Zorluklara İlişkin Değerlendirmeleri İle Sinavlardaki Başar Puanları Arasindaki İlişki Durumu

\begin{tabular}{|c|c|c|c|c|c|c|}
\hline Başarı Puan Türleri & & $\ddot{O} K Z$ & $M / \ddot{O} K Z$ & $\ddot{O} A K Z$ & $F U K Z$ & POKZ \\
\hline Okuma anlama puanı & $\mathrm{r}$ &,$- 292 * *$ &,$- 153 * *$ &,$- 252 * *$ &,$- 150 * *$ &,- 073 \\
\hline Dinleme anlama puanı & $\mathrm{r}$ &,$- 241 * *$ &,$- 158 * *$ &,$- 269 * *$ &,- 087 &,- 098 \\
\hline Yazma puanı & $\mathrm{r}$ &,$- 251 * *$ &,$- 134 *$ &,$- 320 * *$ &,$- 169 * *$ &,- 052 \\
\hline Konuşma puanı & $\mathrm{r}$ &,$- 249 * *$ &,$- 160 * *$ &,$- 266 * *$ &,$- 171 * *$ &,- 094 \\
\hline Toplam Başarı Puanı & $\mathrm{r}$ &,$- 338 * *$ &,$- 198 * *$ &,$- 363^{* *}$ &,$- 193 * *$ &,- 104 \\
\hline
\end{tabular}

Tablo 10'da öğrencilerin öğrendikleri yabancı dilin Okuma-Anlama, Dinleme-Anlama, Yazma ve Konuşma sınavlarındaki akademik başarı düzeyleri ile ÖKZ, M/ÖKZ, ÖAKZ ve FUKZ faktörlerindeki zorlukları yaşama düzeyleri arasında anlamlı ve negatif ilişkilerin bulunduğu $(p<, 05)$ görülmektedir. Öğrencilerin FUKZ faktöründeki zorlukları yaşama düzeyleri ile yalnızca dinleme-anlama puanları arasındaki ilisski anlamlı değildir ( $\mathrm{p}>, 05)$. Diğer taraftan POKZ faktöründeki zorlukları yaşama düzeyleri arasında ise anlamlı olmamakla birlikte negatif yönlü ilişkilerin bulunduğu görülmektedir ( $\mathrm{p}>, 05)$.

\section{Tartışma ve Sonuç}

Araştırma sonunda ulaşılan sonuçlar aşağıda tartışılmıştır.

1. Yabanc1 dil öğrenme süreçlerinde öğrenciler sırasıyla; farklılıklara uyum sağlama, psikososyal ortam, öğrenme alışkanlıkları ve materyal/ölçme değerlendirme faktörlerindeki zorlukları fazla düzeyde; öğretmen kaynaklı zorlukları ise biraz düzeyinde yaşamaktadırlar. Buna göre öğrencilerin genel olarak yabancı dil öğrenme süreçlerinde fazla düzeyde öğrenme zorlukları yaşadıkları; özellikle farklılıklara uyum sağlama kaynaklı zorlukların daha yoğun şekilde yaşandığı söylenebilir. Alanyazında yabancı dil öğrenme süreçlerinde yaşanan sorun ya da zorluklara ilişkin benzer bulgulara rastlandığı çekmektedir. Haznedar $(2010,753)$ bireysel farklılık, motivasyon eksikleri, öğrenmeye ayrilan zaman yetersizliği ve kalabalık sinıf etkenlerinin yabancı dil eğitiminde en baskında sorun alanları olduğunu belirtirken Soyupek $(2007,1572)$ yaşanan zorlukların başında öğrenci ilgisinin temin edilememesi, motivasyon düşüklüğü, öğretim yöntem ve araç-gereçleri ile öğrenme ortamındaki uygunsuzluklar geldiğini; bu zorluk ve sorunların da başarıya önemli ölçüde zarar verdiğini ifade etmektedir. Erişti, Polat ve Erdem (2018) tarafindan uluslararası öğrencilerin bulunduğu İngilizce hazırlık sınıflarında ders veren öğretim elemanlarının öğretim sürecinde karşılaştıkları sorunları sırasıyla yazma becerisi, konuşma becerisi, ölçme ve değerlendirme, sınıf yönetimi, okuma becerisi ve dinleme becerisi konularındaki sorunlar olarak belirlemişlerdir.

KTMÜ'nün dil ve kültür farklılıklarına sahip olan 13 farklı ülkeden öğrenci kabul etmesinin (URL-1) bir sonucu olarak bu öğrencilerin gerek öğrenilen dile ilişkin aksan farklılıkları gerekse bilişsel ve sosyokültürel arka planlarının farklı olmasının öğrenme süreçlerine farklılıkların hâkim olmasını doğurduğu söylenebilir. $\mathrm{Bu}$ farklılıkların bir takım uyum zorluklarını beraberinde getirmesi nedeniyle özellikle farklılıklara uyum sağlama kaynaklı zorlukların daha yoğun yaşanmasını doğurmuş olabilir. Diğer taraftan üniversitede Türk, Kırgız, Rus, Çin, Alman gibi farklı ülkelerden öğretim elemanlarının görev yapıyor olmasının da bir yönüyle kültürel zenginliği sağlarken diğer yönüyle de uyum sağlanması gereken farkllıkları artırmasının da bu sonuç üzerinde etkili olduğu söylenebilir. Erişti, Polat ve Erdem'in (2018, 356-357) tespitleriyle bu yorum tutarll1ık göstermektedir. Diğer taraftan Tutaş’a (2000) göre biyolojik koşullar ile bilişsel ve psikolojik etkenlerdeki farklılıklar gibi durumlar yabancı dil öğrenmeyi olumsuz yönde etkilemektedir (Akt. Altın ve Saracaloğlu, 2018, 156).

2. Öğretmen, materyal-ölçme ve değerlendirme ile öğrenme alışkanllğı kaynaklı yabancı dil öğrenme zorluklarını erkek öğrenciler kızlara göre daha yoğun yaşamaktadırlar. Alanyazında öğrenme tutum, davranış ve stratejileri konusunda cinsiyete göre farklılaşmanın olduğunu (Barut, 2015, 76; Yeşil, 2019, 362; 
Baş, 2012, 22) ve olmadığını (Bay, Gençdoğan ve Tuğluk, 2005, 98) ortaya koyan araştırmaların olduğu gözlenmektedir. Yeşil (2013, 1230), yaptığı çalışmada kız öğrencilerin öğrenme sorumluluklarını yerine getirme konusunda erkeklere göre anlamlı düzeyde daha iyi durumda olduklarını belirlemiştir. Diğer taraftan Illeris (2003), bir sorumluluğun kişisel bir özellik olarak cinsiyete bağlı bir şekilde farklı algyya yol açabileceğini; buna bağlı olarak da farklı sorumlu davranış ve alışkanlıklar geliştirebileceklerini belirtmiştir. Senemoğlu (2011) ise kız öğrencilerin başarı motivasyonlarının daha yüksek olduğunu ve daha sorumlu davrandıklarını ifade etmektedir. Erkek öğrencilerin okul dışı yaşamlarında etkinlik çeşit ve miktarlarının daha fazla olması ögrenme süreçlerinde daha çok zorluk yaşamalarını beraberinde getirmiş olabilir. Barut'a $(2015,76)$ göre toplumsal cinsiyet farklılaşmasına bağlı olarak kız ve erkek öğrenciler arasında kızlar lehine öğrenme sorumluluğunu üstlenme, ögrenme için daha fazla zaman ayırma ve kararlı olma gibi birtakım özelliklerin bulunmasına karşılık erkeklerin görev alanlarının daha fazla yaygın olması ile bu alıskanlıklarında düzensizlikler görülebilmektedir. Erişti, Polat ve Erdem (2018, 356-357) ise dili, kültürü, coğrafyası farklı olan öğrencilerin karışımından oluşan heterojen gruplarda bu farklılıklar nedeniyle bir takım öğretim/öğrenim sorun ve zorlukların yaşandığını işaret etmektedirler.

Diğer taraftan fark anlamlı olmamakla birlikte yalnızca psikososyal ortam kaynaklı zorlukların kız öğrenciler tarafından daha çok yaşandığı dikkati çekmektedir. Bu durum, geleneksel toplum yapısının bir sonucu olarak kızların farklı sosyal ortamlara girme deneyimleri konusundaki sınırlıklarından ve bu nedenle farklı psikososyal ortamlara uyum sağlamada kısmen de olsa zorlanmalarından kaynaklanabilir. Hughes (2001), kadınların erkeklere göre sosyal ortamlarda daha duygusal ve çekingen davranabildiklerini; bunun kadınlığın doğası ile ilişkili olduğunu belirtmektedir.

3. Genel olarak öğrencilerin öğrenim görecekleri bölümlere göre zorluk yaşama yoğunluğu çoktan aza doğru yetenek, sayısal, eşit ağırlık ve sözel bölümlerde öğrenim görecek öğrenciler şeklinde sıralanmaktadır. Özellikle öğretmen ve öğrenme alıskanlığı kaynaklı zorlukları genel yetenek bölümlerinde öğrenim görecek öğrenciler, sözel bölümlerde öğrenim görecek öğrencilere göre daha yoğun yaşamaktadırlar. Diğer taraftan genel olarak bakıldığında yabancı dil öğrenirken öğrenim zorluklarını sözel ve eşit ağıllık bölümlerinde öğrenim görecek olan öğrencilerin genel yetenek ve sayısal bölümlerde öğrenim göreceklere göre daha az yaşadıkları söylenebilir. Bu durum, sözel-dil becerilerini gerektiren bölümlerde öğrenim görecek öğrencilerin dil öğrenme konusunda daha az zorlanmalarr; buna karşıllk özel yetenek ve sayısal bölümlerine yönelen öğrencilerin yabancı bir dil öğrenme konusunda daha çok zorluk çektikleri şeklinde yorumlanabilir. Bu durum aynı zamanda, öğrencilerin motivasyon durumları ile de ilişkilendirilebilir. Sözel ve eşit ağllık bölülerinde öğrenim görecek öğrencilerin bölümlerinde alacakları derslerde sözel iletişimin daha egemen olması ve bu nedenle bölümlerinde başarılı olabilmeleri için öğretim dili olarak da kullanılan yabancı dili daha iyi öğrenmeleri gerektiğine olan inanç ve kabulleri, onları zorluklarla daha etkin mücadele etmeye yönlendirmiş; böylelikle de bu zorlukları aşmalarına yardımcı olmuş olabilir. Zira öğrencilerdeki motivasyonun yabancı dil öğrenme başarısı üzerinde belirleyici etkisi olduğu araştırmacılar tarafindan sıklıkla vurgulanmaktadır (Haznedar, 2010, 753; Altın ve Saracaloğlu, 2018, 156; Yaman, 2018, 173). Soyupek $(2017,1572)$, öğreneceği dili nerede ve nasıl kullanacağı ya da niçin öğrenmesi gerektiği ile ilgili olumlu bir kanaate sahip olmayan bireylerin yabanc1 dili öğrenmeleri çok güçleşmektedir. Arslan $(2009,310)$ ise yeni bir dil edinememenin altında yatan temel sorunlardan birinin motivasyonsuzluk olduğunu belirtmektedir. Ona göre bilim insanları arasında bu konuda genel bir görüş birliği bulunmaktadır. Buna göre bu araştırma sonucunun genel olarak alanyazındaki açıklamalarla tutarlılık gösterdiği söylenebilir.

4. Değerlendirmeleri alınan öğrencilerin yabancı dil öğrenmede zorluk yaşama durumları; ana dilleri, yaşadıkları ülkelerde yoğun olarak konuşulan dil sayıları, öğrendikleri yabancı dil ve ailelerinin Kırgızistan'da yaşama durumuna göre özellikle ÖKZ ve ÖAKZ faktörlerinde farklılaşmaktadır. Ana dili Türkiye Türkçesi ve diğer diller olan öğrenciler Kırgız Türkçesi ana diline sahip öğrencilere göre; ülkelerinde yoğun olarak konuşulan dil sayısı az olanlar çok olanlara göre; yabanc1 dil olarak Kırgız Türkçesi öğrenen öğrenciler, Türkiye Türkçesi ve diğer dilleri öğrenenlere göre; aileleri Kırgıistan dışından yaşayanlar Kırgızistan'da yaşayanlara göre yabancı dili öğrenirken anlamlı bir farkla daha fazla zorluk yaşamaktadırlar. Bu durum, genel olarak başta Kırgız Türkçesi ve Rusçayı ana dili gibi bilen ve aynı zamanda ülkelerinde başta Rusça ve Kırgız Türkçesi olmak üzere Uygur, Özbek, Kazak Türkçesinin de içinde yer aldığı çok sayıda dilin konuşulduğu bir ülke olan Kırgızistanlı öğrencilerin farklı bir dili öğrenirken daha az zorluk çektikleri şeklinde yorumlanabilir. 
Bu durum, farklı nedenlere dayalı olarak açıklanabilmekle birlikte; küçük yaşlardan itibaren Kırgız ögrencilerin farklı dillere aşina olmaları, en az iki dili ana dil düzeyinde biliyor olmaları nedeniyle yeni bir dili öğrenme deneyimine sahip olmaları, Kırgızistan'da dil öğrenme kursları ya da imkânlarını daha iyi bilmeleri ve bunlardan yararlanabilmelerinin etkili olduğu söylenebilir. Burada özellikle küçük yaşlarda yabancı bir dili öğrenme deneyimi ile kulak aşinalığı ve egzersiz yapma imkânlarına sahiplik durumlarının yabanc1 bir dili öğrenirken zorlukları aşmada önemli katkılar sağladığı sonucu çıkarılabilir. Alanyazında yabanc1 dili öğrenmeye başlamanın küçük yaşlarda olmasının gerektiğinin sıklıkla vurgulandığ dikkati çekmektedir (Arslan, 2009, 310; Gömleksiz ve Özkaya, 2012, 497). Diğer taraftan küçük yaşlarda dil ögrenme konusundaki deneyim fazlalı̆ı̆na dayalı olarak dil öğrenme konusundaki öğrenme alışkanlıklarının da iyileşmesi söz konusu olabilir. Nitekim öğrenme sorumluluğu ve düzenli ders çalısma alışkanlıklarına sahip olmakla ve öğrenme için yeterli zaman ayarlamasını yapmakla öğrenme başarısı arasında olumlu ilişskilerin bulunduğunu ortaya koyan pek çok araştırma bulunmaktadır (Soyupek, 2007, 1572; Barr \& Tagg, 1995; Carnell, 2005; Hughes, 2001; Sierra, 2009; Young, 2005). Yeşil (2019, 363), öğrencilerin Türkiye Türkçesini öğrenme uygulamalarını yapma sıklıklarını incelediği çalışmasında öğrencilerin bildikleri dil sayısı fazla olan öğrencilerin öğrenme uygulamalarını daha sık yaptıklarını ve motivasyonlarının yüksek olduğunu belirtmiştir.

Bunların yanı sıra, yukarıda da değinildiği üzere bilim insanları tarafindan sıklıkla dile getirilen bir başka değişken ise dil öğrenmeye karşı öğrencilerin motivasyonlarının olmasıdır (Haznedar, 2007; Soyupek, 2007; Erişti, Polat ve Erdem, 2018; Altın ve Saracaloğlu, 2018; Illeris, 2003; Barut, 2015, 29-31). Kırgıı öğrencilerin geleceklerini Türkiye ya da Avrupa ülkelerinde görmeleri, oralarda kullanacakları yabancı dili öğrenme motivasyonlarının da zorlukları aşma konusunda öğrencilere yarar sağladığı (Cuma, 2017, 193 195; Yeşil, 2019, 363-364) söylenebilir. Nitekim Barut $(2015,66)$ tarafindan yapılan çalşsmada öğrencilerin Türkiye'de iş bulabileceklerine inanmaları nedeniyle Türkiye Türkçesini öğrenmeye istekli oldukları; bu nedenle de dil öğrenmeleri için yapmaları gereken öğrenme uygulamalarında daha kararlı davrandıkları belirlenmiştir.

5. Öğrencilerin öğrendikleri yabancı dilin Okuma-Anlama, Dinleme-Anlama, Yazma ve Konuşma sınavlarındaki akademik başarı düzeyleri ile ÖKZ, M/ÖKZ, ÖAKZ ve FUKZ faktörlerindeki zorlukları yaşama düzeyleri arasında anlamlı ve negatif ilişkiler bulunmaktadır. Diğer taraftan POKZ faktöründeki zorlukları yaşama düzeyleri ile akademik başarı düzeyleri arasında ise anlamlı olmamakla birlikte negatif yönlü ilişkiler bulunmaktadır. İlişkilerin negatif olması, zorlukların etkisi azaldıkça akademik başarının arttığı şeklinde yorumlanabilir. Alanyazında yaşanan sorunlara ve öğrenme zorluklarına bağlı olarak yabanc1 dil öğrenme başarılarının beklenen ya da istenen düzeyde sağlanamadığına ilişkin çok sayıda araştırmada yapilan tespitlerle bu araştırma bulgusunun örtüştüğü söylenebilir (Soyupek, 2007; 1572, Erişti, Polat ve Erdem, 2018, Gömleksiz ve Özkaya, 2012; Haznedar, 2010; Altın ve Saracaloğlu, 2018; Arslan, 2009; Yaman, 2018). Başka bir ifade ile öğrencilerin öğrenim zorlukları yaşama miktarlarının azaltılması ya da onlara zorlukları aşma yollarının öğretilmesinin, dil becerilerini öğrenme başarılarına olumlu katkılarının olacağı söylenebilir.

\section{Öneriler}

Öğrencilerin yabancı dil öğrenirken yaşadıkları zorlukları belirlemeyi ve belirli değişkenler açısından incelemeyi amaçlayan bu çalışma sonunda yaşanan zorlukların etkisini azaltmak ya da öğrenmelerini kolaylaştırmak üzere şu önerilerde bulunulabilir:

1. Yabanc1 dil öğrenme-öğretme süreçlerinde, yalnızca dil öğretmek üzerine odaklanılmayıp, yaşanabilecek zorlukları aşma ve öğrenmeyi öğrenme yeterliklerinin kazandırılmasına/geliştirilmesine dönük eğitim etkinliklerine de yer verilmelidir. Bu çerçevede gerek ders süreçlerinde gerekse bağımsız olarak yabancı dil nasıl daha iyi ve kolay öğrenilebilir konuları ile öğrenme alışkanlıkları ve sorumlulukları konusunda öğrencilerin öncelikli olarak bilinçlendirilmesinin yararlı olacağ1 söylenebilir. Bu konularda ögretim elemanlarının zaman zaman öğrencilerine yönlendirici ve cesaret verici açılamalarda bulunmaları önerilebilir. Bu konularda öğretim elemanlarının da bilgi ve bilinç sahibi olmaları gerektiği belirtilmelidir.

2. Öğrencilerin yabancı dil öğrenme zorluklarını aşma konusunda öğrencilere dönük düzenlenecek ek kurs ya da eğitim çalışmalarında özellikle; 
a. Başta farklı dil öğrenme ve öğretme tarzları ile dili farklı telaffuz etme farklılıkların olumsuz etkilerinden korunma, öğrenci arkadaşları ile farklı psikososyal ortamlarda birlikte bulunma ve karşılıklı yardımlaşma stratejilerini öğrenmelerine;

b. Öğrencilerin, her ne kadar bazı sorunlara kaynaklık da etse (Erişti, Polat ve Erdem, 2018, 357) ana dil, bölüm, ülke ve cinsiyet açısından heterojen çalışma grupları ile birlikte dil öğrenme çalışmalarına özendirilmesine önem verilmelidir.

3. Öğretmenlere dönük öğrencilerin yaşadıkları zorlukları aşmalarına etkin yardım etmelerine dönük yapılabilecek eğitim çalışmalarında ise

a. Heterojen grup oluşturma ve çalışmaların yönetimi;

b. İşbirlikli öğrenme yönteminin ders içinde ve ders dışında etkin kullanımı;

c. Öğrencilerin bireysel farklılıklarını (dil, kültür, öğrenme tarzı, cinsiyet vb.) dikkate alarak dil öğretimini planlama ve uygulama becerilerinin geliştirilmesine;

d. Öğretim materyali geliştirme, yararlanma, işbirlikli öğrenme yöntemini etkin kullanma ve yabancı dil öğretiminde alternatif ve etkin ölçme değerlendirme yöntemlerinden yararlanabilme bilgi ve becerilerinin geliştirilmesine önem verilmelidir.

4. Diğer taraftan, okulun bulunduğu şehirdeki destekleyici yabancı dil öğrenme imkan ve firsatları konusunda öğrencilere rehberlik edilmesi; bu çerçevede bir oryantasyon programının uygulanması ya da öğrencilere bu içerikte doküman dağıtılması yararlı olabilir.

5. Öğrencilerin okul ve ev ortamlarında dikkat ve gayretlerini öğrenme üzerine odaklayabilmeleri için öğrenme çalışmaları dışında farklı işlerle uğraşarak zaman kaybı yaşamalarının önüne geçilmeye çalışılmalı; onların yemek, temizlik ve düzen gibi ihtiyaçlarının kurumlar tarafından giderilmesine dönük önlemler almaları yararlı olabilir. Bu çerçevede öğrenci yurtlarının kapasiteleri ve hizmet çeşitleri iyileştirilmesi yararlı olabilir.

6. Kırgız öğrencilerin yabanc1 dil öğrenmedeki başarılarının nedenleri ile ilgili olarak kendi ülkelerinde bulunma, en az iki dil biliyor olma, aileleri ile birlikte yaşıyor olma gibi değişkenlerin etkilerine ilişkin detaylı tespitlerde bulunulup diğer öğrenciler için de bu doğrultuda alınabilecek tedbirlerin alınmaya çalışılması önerilebilir. Bu konularda araştırma sayılarının artırllması ve özellikle deneysel araştırmaların yapılması önerilebilir.

\section{Etik Beyan}

"Üniversite Öğrencilerinin Yabancı Dil Öğrenme Zorluklarm Yaşama Düreyleri” başlıklı çalışmanın yazım sürecinde bilimsel, etik ve alıntı kurallarına uyulmuş; toplanan veriler üzerinde herhangi bir tahrifat yapılmamış ve bu çalışma herhangi başka bir akademik yayın ortamına değerlendirme için gönderilmemiştir.

\section{Kaynakça}

Altın, A. ve Saracaloğlu, A. S. (2018). İngilizce öğretimindeki ihtiyacımız nedir? Bir olgu bilim çalışması. Dil Eğitimi ve Arasttrmalar Dergisi, 4(2), 137-159. DOI: http://dx.doi.org/10.31464/jlere.379358.

Balcı, A. (2015). Sosyal bilimlerde arastırma: Yöntem, teknik ve ilkeler. Ankara: Pegem Akademi Yayınevi.

Barr, B. R. ve Tagg, J. (1995). From teaching to learning: A new paradigm for undergraduate education. Change, 27(6), 697-710.

Barut, A. (2015). Yabanc dil olarak Türkşe ögrenen üniversite ögrencilerinin kullandıklar dil ögrenme stratejileri üzerine bir değerlendirme (Yüksek Lisans Tezi). Bilkent Üniversitesi Eğitim Bilimleri Enstitüsü Eğitim Programları ve Öğretim ABD, Ankara.

Baş, G. (2012). Lise öğrencilerinin kullandıkları dil öğrenme stratejilerinin bazı değişkenler açısından incelenmesi. Dil Dergisi, 156, 7-28.

Bay, E., Tuğluk, M. N. ve Gençdoğan, B. (2005). Üniversite öğrencilerinin ders çalışma becerilerinin incelenmesi, Elektronik Sosyal Bilimler Dergisi, 4(14), 94-105.

Bayır, M. ve Yeşil, R. (2019). Yabancı dil öğrenme zorlukları ölçeğinin geçerlik ve güvenirlik çalısması. Manas Sosyal Araştırmalar Dergisi, 8(2), 1573-1590. DOI: https://doi.org/10.33206/mjss.530574.

Büyüköztürk, Ş. (2012). Sosyal bilimler için veri analiz̨i el kitabı. Ankara: Pegem Akademi Yayınları.

Carnell, E. (2005). Understanding and enriching young people's learning: issues, complexities and challenges. Improving Schools, 8(3), 269-284. 
Cuma, F. İ. (2017). Yabancı dil olarak Türkçe öğretiminde öğrenci memnuniyeti. SEFAD, 38, 179-196.

Erişti, B., Polat, M. ve Erdem, C. (2018). Yükseköğretimde uluslararasılaşma: uluslararası öğrencilerin bulunduğu sınıflarda ders veren öğretim elemanlarının öğretim sürecinde yaşadıkları sorunlar ve çözüm önerileri. Journal of History Culture and Art Research, 7(2), 352-375. doi:http://dx.doi.org/10.7596/taksad.v7i2.1539

Eroğlu, A. (2008). Faktör analizi. İçine Ş. Kalayc1 (Edt.). SPSS uygulamal çok değişkenli istatistik teknikleri (ss. 321-331). Ankara: Asil Yayın Dağıtım.

Gömleksiz, M. ve Özkaya, Ö.M. (2012). Yabancı diller yüksekokulu öğrencilerinin İngilizce konuşma dersinin etkililiğine ilişkin görüşleri. Turkish Studies - International Periodical For The Languages, Literature and History of Turkish or Turkic. $7(2), 495-513$.

Haznedar, B. (2010). Türkiye'de Yabanc1 Dil Eğitimi: Reformlar, Yönelimler ve Öğretmenlerimiz. International Conference on New Trends in Education and Their Implications (11-13 November, 2010 Antalya-Turkey), ss. 747-755. ISBN: 9786053641049

Hughes, C. (2001). Developing conceptual literacy in lifelong learning research: a case of responsibility?. British Educational Research Journal, 27(5), 601-614.

Illeris K. (2003). Learning, identity and self-orientation in youth. Young, 11(4), 357-376. DOI: 10.1177/11033088030114004. [Online]: http://you.sagepub.com/content/11/4/357 adresinden 05.02.2011'de indirilmiştir.

Karasar, N. (2012). Bilimsel araștırma yöntemi (23. Bask1). Ankara: Nobel Yayınevi.

Senemoğlu N. (2011). College of education students' approaches to learning and study skills. Eğitim ve Bilim-Education and Science, 36(160), 65-80.

Sierra, J. J. (2009). Shared responsibility and student learning : Ensuring a favorable educational experience. Journal of Marketing Education, 32, 104-111. DOI: 10.1177/0273475309344802. [Online]: http://jmd.sagepub.com/content/32/1/104 adresinden 15.11.2011'de indirilmiştir.

Soyupek, H. (2007). Yabanc1 dil öğretiminde güdülemenin önemi. Uluslararası Asya ve Afrika Calısmalar Kongresi, ICANAS 38, (10-15 Eylül 2007), Bilkent Üniversitesi, Ankara, ss. 1571-1588.

Suna, Y. ve Durmuşçelebi, M. (2013). Türkiye'de yabancı dil öğrenme-öğretme problemine ilişkin yapılan çalışmaların derlemesi. Türkiye Sosyal Politika ve Calişma Hayatı Araștırmalar Dergisi, 3(5), 7-24.

Yalçın, Ş. (2013). İçerik temelli yabancı dil öğretim modeli. Boğaziçi Üniversitesi Eğitim Dergisi, 30(2), 107-121.

Yaman, İ. (2018). Türkiye'de İngilizce öğrenmek: Zorluklar ve firsatlar. RumeliDE Dil ve Edebiyat Arasstırmalar Dergisi, $11,161-175$.

Yeşil, R. (2013). Ortaöğretim öğrencilerinin okul öğrenmelerindeki öğrenme sorumluluklarını yerine getirme düzeyleri. International Journal of Human Sciences, 10(1), 1214-1237

Yeşil, R. (2019). Öğrencilerin Yabancı Bir Dil Olarak Türkiye Türkçesini Öğrenme Uygulamalarının Farklı Değişkenler Açısından İncelenmesi. International Journal of Languages' Education and Teaching, 7(1), 348-367, DOI: 10.18298/ijlet.3227.

Yolcu, M. (2002). Yabancı dil öğrenimi. Dinbilimleri Akademik Araştırma Dergisi II(3), 19-72.

Young, M.R. (2005). The motivational effects of the classroom environment in facilitating self-regulated learning. Journal of Marketing Education, 27(1), 25-40. DOI: 10.1177/0273475304273346.

\section{EXTENDED ABSTRACT}

The world has become a village with the development in communication and transportation technologies. Geographical distances are no longer a problem for communication and interaction between people. Nevertheless, it cannot be said that communication problems between people have disappeared. Significant problems continue to arise mainly in the communication of individuals who speak in different languages. It can be said that the fact that they cannot communicate because of the language barriers despite geographical convergence with the help of technology makes learning a different foreign language a more meaningful issue.

Individuals, communities and even governments make significant investments to overcome this issue. Opening of foreign language teaching schools, arranging foreign language courses for individuals of all ages, placing foreign language courses up to pre-school educational programs, arranging many scientific and social activities related to foreign language teaching, making legal formations in which foreign language speakers will be more advantageous, these can be given as example of mentioned investments and efforts. Even so, problems and difficulties with foreign language learning and teaching continue. However, it should be noted that numerous researches and scientific studies continue to be carried out in order to overcome these problems and difficulties every single day.

In the context of this article, besides the theoretical studies in the literature, an important part of the research is determined to the attitudes and habits of students towards learning a foreign language and their 
levels of success; it is observed that teachers are examining teaching competencies. On the other hand, it can be said that the researches related to defining the learning difficulties faced by the students in the process of learning a foreign language have not been conducted sufficiently. The main issue of this study is to examine the learning difficulties faced by students in foreign language learning-teaching processes and levels of these difficulties in terms of different variables. Thus, in order to facilitate a process of learning a foreign language, article was aimed to make determinations that could be a clue about the measures that could be taken by both students and faculty students.

The research is a descriptive study carried out in a quantitative and screening model. The study group of the research consists of 495 students who study in foreign language preparatory classes of KyrgyzTurkish Manas University. The data of the study was collected by "Personal Information Form (PIF)" and "Foreign Language Learning Scale of Difficulties (FLLSD)".

PIF was about to collect data on the unbundled variables of the study and consists of 7 questions. FLLSD, on the other side, is a five-point Likert type scale consisting of 29 items assembled under 5 factors. Factors of the scale; "Teacher-based Difficulties", Material / Measurement-Based Difficulties", "Learning Habit-Based Difficulties", "Difficulties based on Adaptation to Differences" and "Difficulties Based on Psychosocial Environment». The scale was graded as (0) none / very little", "(1) little", "(2) slightly / partially", 3 (3) over" and "(4) too much. PIF value of FLLSD was 0.937; Bartlett Test values x2 $=5707,914 ; \mathrm{SD}=406 ; \mathrm{p}<0.001 ;$ The Cronbach alpha reliability co-efficient was 0.923. Arithmetic mean, standard deviation, $\mathrm{t}$ test, ANOVA, Tukey and correlation test analyzes were carried out with the data. In the interpretation of difference and relationship tests, $\mathrm{p}<0.05$ level was considered to be enough for significance.

At the end of the research, the following main conclusions were reached in coordination with literature:

1. Students, turn by turn, experience high level difficulties in adaptation to differences, psychosocial environment, learning habits, and difficulties in material /measurement and evaluation; and teacher-based difficulties at medium level.

2. In comparison with girls boys more intensively experience problems with learning a foreign language based on teachers, learning habits, material-measurement and evaluation.

3. In general, the intensity of having difficulty according to the departments where the students will study is listed as talent, quantitative, equal complexity, and students who will study in verbal departments.

4. Students' difficulties in learning a foreign language differs according to their mother tongue, the number of languages spoken intensively in the countries they live in, the foreign language they learn, and the difficulties connected with the teacher and the habit of learning. Especially Kyrgyz students experience fewer difficulties in learning a foreign language.

5. There are significant and negative relationships between the difficulties that students experience with academic achievements in reading-comprehension, listening-comprehension, writing and speaking exams.

The results were verified in coordination with research analysis found in literature and the following suggestions were made:

1. Foreign language learning-teaching processes shouldn't focus only on teaching languages, but they also should include activities aimed at acquiring the competence to overcome the difficulties that may be faced.

2. Additional courses or educational activities organized for the students should include protection from differences in learning-teaching styles and pronunciation, strategies for facilitating language learning among students should be built.

3. Foreign language learning activities should be conducted by creating heterogeneous working groups with regard to mother tongue, department, country and gender.

4. Within the framework of foreign language teachers' training the following skills especially demanded to be acquired: to create and manage heterogeneous groups, to use cooperative learning 
method effectively, to plan and conduct language teaching according to individual differences, to be able to benefit from complementary (alternative) measurement and evaluation techniques.

5. The reasons why Kyrgyz students have less difficulty in learning a foreign language and strategies to overcome these difficulties should be investigated more thoroughly. 